\title{
Videosonde-Observed Graupel in Different Rain Systems during Pre-YMC Project
}

\author{
Kenji Suzuki ${ }^{1}$, Katsuhiro Nakagawa ${ }^{2}$, Tetsuya Kawano ${ }^{3}$, Shuichi Mori ${ }^{4}$, \\ Masaki Katsumata ${ }^{4}$, Fadli Syamsudin ${ }^{5}$, and Kunio Yoneyama ${ }^{4}$ \\ ${ }^{1}$ Graduate School of Sciences and Technology for Innovation, Yamaguchi University, Yamaguchi, Japan \\ ${ }^{2}$ National Institute of Information and Communications Technology, Koganei, Japan \\ ${ }^{3}$ Department of Earth and Planetary Sciences, Kyushu University, Fukuoka, Japan \\ ${ }^{4} J a p a n$ Agency for Marine-Earth Science and Technology, Yokosuka, Japan \\ ${ }^{5}$ Agency for the Assessment and Application of Technology, South Tangerang, Indonesia
}

\begin{abstract}
Videosonde observations were conducted at the southwestern coastal region of Sumatra Island, Indonesia, as part of a pilot field campaign of the Years of the Maritime Continent project (PreYMC), to investigate the role of solid hydrometeor for precipitation processes in clouds. Videosondes were launched into three types of clouds: convective and stratiform clouds, and a thick upper stratiform cloud with shallow convection at lower level. A quantitative evaluation of the graupel shape data obtained from the videosondes showed different graupel formations in different rain systems. For the typical stratiform cloud, almost no graupel was observed. In contrasts, for the thick upper stratiform clouds with shallow convection, large numbers of ice crystals in the upper layer suggested to act as embryos and form a lot of graupel with the riming of the supercooled droplets that was supposed to be provided from the shallow convection. On the other hand, for the convection case, the videosonde observed spherical graupel just above the freezing level. This suggested that frozen drops acting as embryos formed spherical graupel, which were uplifted by the strong updraft in the convective cloud, and were different from the generally irregular-shaped graupel in the thick upper stratiform cloud.
\end{abstract}

(Citation: Suzuki, K., K. Nakagawa, T. Kawano, S. Mori, M. Katsumata, F. Syamsudin, and K. Yoneyama, 2018: Videosondeobserved graupel in different rain systems during Pre-YMC Project. SOLA, 14, 148-152, doi:10.2151/sola.2018-026.)

\section{Introduction}

Solid hydrometeors, which are classified into ice crystal, graupel, snowflake, etc., are formed through various processes such as deposition, riming, and aggregation. They melt at temperatures above $0^{\circ} \mathrm{C}$ and form raindrops, resulting in rainfall at the surface. The distributions of the densities, as well as shapes and size, of solid hydrometeors in a cloud vary with the height and temperature.

Graupel is one of solid hydrometeors, which is generally a white, opaque, conical/spherical pellet with a diameter of up to 5-6 mm, as a result of the accretion of supercooled droplets on ice embryos. The shapes of graupel have been investigated in many experimental and observational studies. Knight and Knight (1973) observed conical graupel in winter at Elk Mountain, Wyoming. Harimaya (1976) classified graupel based on the type of embryo in polarization microscopy measurements. Conical graupel was often observed in winter snow clouds that developed along the Japan Sea (e.g., Takahashi et al. 1999; Watanabe et al. 2014). On the other hand, spherical graupel were sometimes observed just above the freezing level in convective clouds during the Baiu rainy season in Okinawa (Suzuki et al. 2014).

It is important to know the solid hydrometeor density for the understanding of the precipitation processes since the density

Corresponding author: Kenji Suzuki, Yamaguchi University, 1677-1 Yoshida, Yamaguchi 753-8515, Japan. E-mail: kenjis@yamaguchi-u.ac.jp. is strongly related to the concentration of the water in the cloud through the various hydrometeor formation processes. However, it is difficult to measure the density of precipitation particles directly in clouds. Therefore, we discuss the precipitation particle formation process using information on the particle size and shapes obtained from the particle images.

A powerful tool for capturing particle images in clouds is a videosonde. It can capture the particle image in the air without contact, which is a big advantage as it can provide nondestructive images of the ice particles. The videosonde was first developed by Takahashi (1990) and improved by Suzuki et al. (2012). Improvements in the quality of the particle images and the development of an image processing technique allowed the quantitative evaluation of the size and shape of the precipitation particles (Suzuki et al. 2012).

During November to December 2015, videosonde observations were conducted as part of a pilot field campaign the Years of the Maritime Continent project (Pre-YMC) for better understandings of microphysical features in tropical precipitating clouds. The PreYMC campaign is an observation campaign over the southwestern coastal region and adjacent sea of Sumatra Island, Indonesia, to examine the atmosphere-ocean-land coupling processes related to coastal heavy rain. The coastal heavy rain is characterized by active convection with a clear diurnal cycle (Takayabu 2002; Mori et al. 2004), and associated with the Madden-Julian Oscillation (MJO) (Wu et al. 2017).

In the past videosonde studies in the tropics, Takahashi et al. (1995) launched videosondes during the Tropical Ocean and Global Atmosphere Coupled Ocean-Atmosphere Response Experiment (TOGA-COARE) project and observed the dominant warm rain and freezing process in tropical convective clouds. Videosonde observations in the Maritime Continent showed that heavily-precipitating clouds contain many of graupel and frozen drops (Takahashi 2006). However, in past videosonde observational studies, the low-resolution images did not allow us to evaluate the detailed shape of the particles.

In this study, we launched new-generation videosondes (Suzuki et al. 2012) into different types of rain systems over the southwestern coast of Sumatra Island, Indonesia during the Pre-YMC campaign. Utilizing the obtained data, we evaluate precipitation particle formation processes in clouds, by focusing on the shapes of graupel.

\section{Observation}

\subsection{Pre-YMC project}

For better understandings of the rain systems that develop along the Sumatra Island coastal area, the Pre-YMC observation campaign was carried out off and on Sumatra, Indonesia (Yokoi et al. 2017). The Maritime Continent consists of a large number of big and small islands, and most of the rainfall is concentrated in the coastal areas (Ogino et al. 2016). Torrential rainfall along the coastal areas is produced by diurnal convections, which is strongly modulated by large-scale disturbances such as the MJO and monsoons (Mori et al. 2011). 


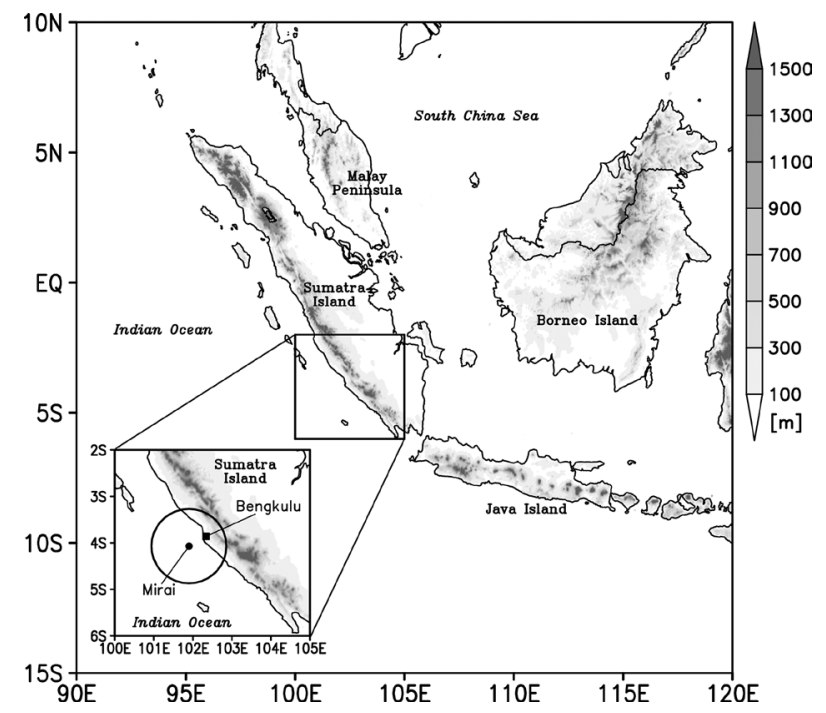

Fig. 1. Locations of the videosonde launch site (the Bengkulu Meteorological Observatory) and the R/V Mirai.

Surface meteorological observations and intensive upper air soundings were conducted at the Indonesian Agency for Meteorology, Climatology and Geophysics (BMKG) Bengkulu Meteorological Observatory $\left(3.86^{\circ} \mathrm{S}, 102.34^{\circ} \mathrm{E}\right)$ (hereafter referred to as the Bengkulu site) during IOP from 9 November to 25 December 2015. The R/V Mirai stayed at the station about $50 \mathrm{~km}$ offshore from 22 November to 17 December, as shown in Fig. 1. After a videosonde was launched from the Bengkulu site, a range height indicator (RHI) scan by the C-band polarimetric radar onboard the $\mathrm{R} / \mathrm{V}$ Mirai was conducted, targeting the launched videosonde. Videosondes can measure precipitation particles in clouds directly and provide microphysical information such as vertical profiles of precipitation particles, while the C-band radar of the R/V Mirai can provide the 3-dimensional structures of precipitating clouds. It is the world-first opportunity to obtain data of the precipitating cloud simultaneously by the videosonde and shipboard polarimetric radar.

The BMKG Surface synoptic observation (SYNOP) showed a typical diurnal pattern of lightning with a peak at 18:00 Local Standard Time (LST $=$ UTC +7 ), as well as the diurnal variation of the rainfall, during the Pre-YMC campaign (before 13 December). According to the 3-hourly intensive upper air soundings, the specific humidity decreased dramatically, and the land-sea circulation was not clear after the strong westerly wind was observed on 13 December. After that, no lightning was observed, and the rain type was changed to continuous rain.

\subsection{Videosonde}

The videosonde was originally developed by Takahashi (1990), for better understandings of precipitation mechanisms in clouds. The videosonde is a balloon-borne radiosonde specially designed to be launched into precipitating clouds, and has a charge-coupled diode (CCD) camera and a strobe to capture particle images in the air and to provide information on the particle size and shape. Images of particles were transmitted to the receiving system located on the roof of the Bengkulu site before being displayed and recorded. Suzuki et al. (2012) developed a new videosonde receiving system and further improved the videosonde to be lowcost, light weight, and providing sharper images. As a result, the quantitative evaluation of particle shapes is possible from videosonde images. Frames in the motion image data captured by the CCD camera are binarized and the outlines of particles are extracted using threshold values. The major and minor diameters, circumferential lengths, and areas of particles are calculated. In addition, the circularity $(\mathrm{C})$ and the ratio of the short diameter and the long diameter (hereafter the diameter ratio: $R_{d}$ ) are calculated as follows (Muramoto et al. 1993):

$$
\begin{aligned}
& \mathrm{C}=\frac{4 \pi A}{L^{2}} \\
& R_{d}=\frac{D_{\text {short }}}{D_{\text {long }}}
\end{aligned}
$$

where $A$ is the area of a particle on the monitor, $L$ is its circumferential length of a particle, and $D_{\text {long }}$ and $D_{\text {short }}$ are its major and minor diameters of a particle, respectively. If a particle is completely spherical, then the circularity of the particle is 1 , and as the shape of the surface becomes more complicated, the circularity decreases. Here, the diameter ratio refers to the flatness of the particle. After the image processing, the recorded precipitation particles were classified as raindrops, frozen (or partially melted) drops, graupel, ice crystals, or snowflakes based on their transparency and shape (Takahashi and Keenan 2004; Suzuki et al. 2014). Frozen drop is characterized by mostly or partially semi-transparent irregular shape with smooth outlines, while graupel is whiter on the entire surface of the particle with jaggier outlines, as a result of riming. Videosonde observations were carried out from 23 November to 17 December 2015 during the Pre-YMC campaign. In total, 18 videosondes were launched from the Bengkulu site into precipitating clouds that developed over the southwestern coastal area of Sumatra Island. In this study, three different rain types observed by videosondes were selected for analysis: (1) convective type (CT), (2) shallow convective case embedded under the upper anvil cloud (ECT), and (3) typical stratiform type (ST).

\section{Results}

\subsection{Case of a convective cloud (CT)}

On 30 November 2015, the edge of a broad cloud, which extended over the area east of the observation site, developed and produced convective rain at the Bengkulu site (Fig. 2a). A videosonde (hereafter referred to as videosonde-CT) was launched into the convective cloud at 20:03 LST. The altitude of $0^{\circ} \mathrm{C}$ was $4.9 \mathrm{~km}$, and the videosonde-derived cloud top was approximately $9 \mathrm{~km}$. Videosonde-CT transmitted images of raindrops $>6 \mathrm{~mm}$ in diameter in the lower level of the cloud, and frozen drops at around the $0^{\circ} \mathrm{C}$ level (Fig. 3a). In addition, many spherical graupel were observed just above the level where the frozen drops were observed, whose diameters were 0.5 to $4 \mathrm{~mm}$. In the upper level of the cloud, few ice crystals were observed. This vertical distribution of precipitation particles was similar to that of the typical tropical convective clouds observed by Takahashi and Kuhara (1993) and Takahashi et al. (1995), in which the warm rain and freezing process were dominant, as shown in Table 1.

\subsection{Case of a shallow convection embedded under the upper anvil cloud (ECT)}

On 25 November 2015, a clear diurnal convection, which was characterized by clear sky in the morning and thunderstorms in the afternoon, was observed. In the evening, a strong tall convective cloud developed $10 \mathrm{~km}$ far from the observation site (Fig. 2b). Over the observation site, an anvil cloud extended from the neighboring strong convection, and we observed rain from a newly formed cloud with updraft at the lower level due to the convergence of the outer flow from the neighboring strong convection and environmental wind flow, which was observed by the R/V Mirai radar (not shown). A videosonde (hereafter referred to as videosonde-ECT) was launched at 18:40 LST into this lower convective cloud that developed next to the strong tall convection. The altitude of $0^{\circ} \mathrm{C}$ was $4.8 \mathrm{~km}$, and the cloud top was approximately $12 \mathrm{~km}$. Videosonde-ECT observed raindrops $>4 \mathrm{~mm}$ in diameter were observed below the freezing level (Fig. 3b). Near and above the freezing level, snowflakes and a lot of graupel were observed. It was considered that the graupel formation was enhanced in comparison with that of a typical stratiform cloud (Suzuki et al. 2016). 


\section{(a) $\mathrm{CT}$}

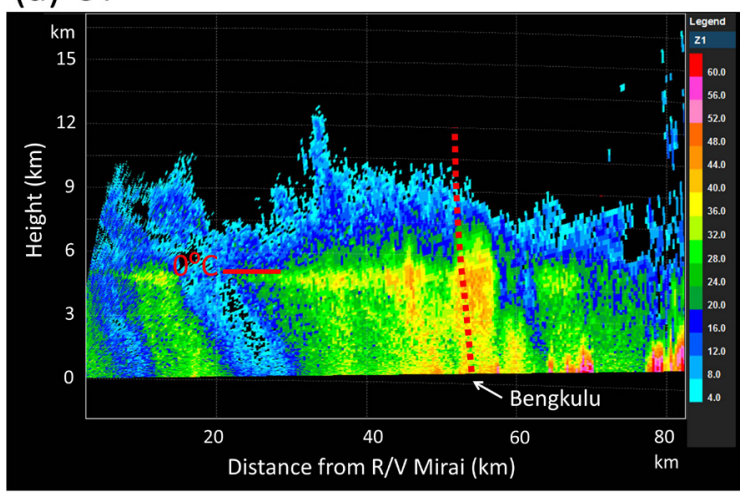

(b) ECT

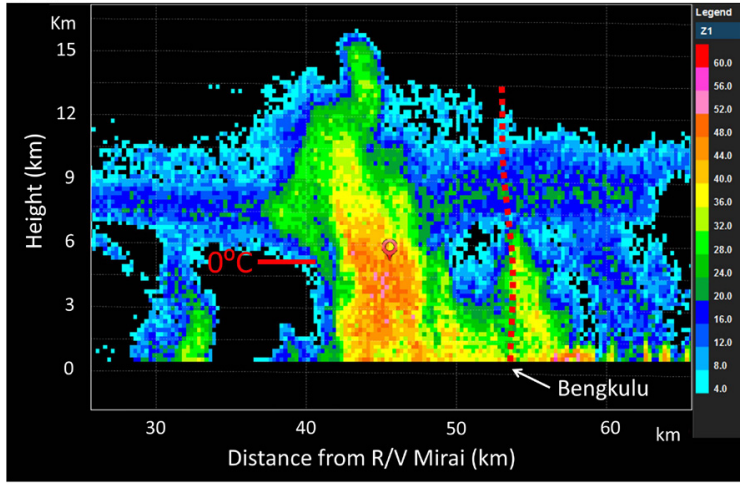

(c) ST

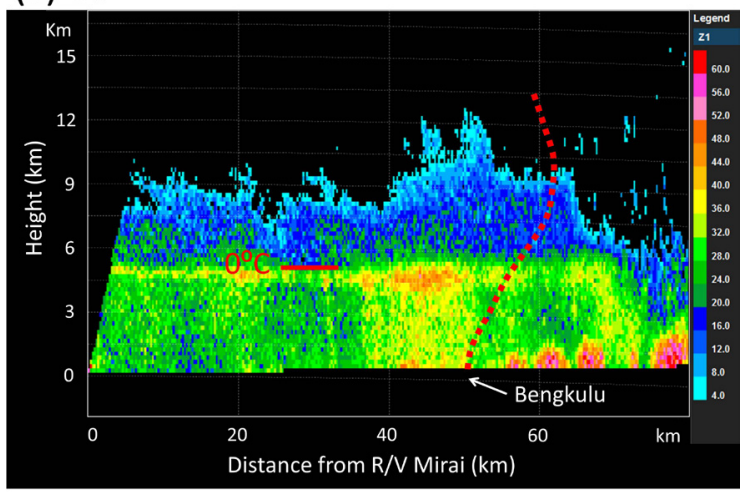

Fig. 2. R/V Mirai radar RHI images at (a) 20:05 LST on 30 November 2015; (b) 18:45 LST on 25 November 2015; and (c) 21:14 LST on 15 December 2015. Red dot lines indicate the trajectories of videosondes.

Table 1. Volume ratio (\%) of liquid and solid hydrometeors calculated as the proportion of volume to the total volume of the precipitation particles throughout the clouds. For the solid hydrometeors, volume ratios were calculated for each particle to the total solid hydrometeors. Values in brackets show mass contribution ratio (\%) calculated, assuming the densities of raindrops, frozen drops, graupel, ice crystals, and snowflakes were assumed to be $1.0,0.9,0.3,0.1$, and $0.1 \mathrm{~g} \mathrm{~cm}^{-3}$, respectively.

\begin{tabular}{lccc}
\hline & CT & ECT & ST \\
\hline Liquid & $\mathbf{9 7 . 7 \% ( 9 9 . 1 \% )}$ & $\mathbf{6 4 . 4 \% ( 8 6 . 9 \% )}$ & $\mathbf{2 6 . 8 \% ~ ( 7 7 . 4 \% )}$ \\
\hline Solid & $\mathbf{2 . 3 \% ( \mathbf { 0 . 9 } \% )}$ & $\mathbf{3 5 . 6 \% ( 1 3 . 1 \% )}$ & $\mathbf{7 3 . 2 \% ( 2 2 . 6 \% )}$ \\
Frozen drop & $21.7 \%(53.2 \%)$ & $0.6 \%(1.5 \%)$ & $-(-)$ \\
Graupel & $60.9 \%(42.6 \%)$ & $59.2 \%(64.9 \%)$ & $3.6 \%(10.2 \%)$ \\
Ice crystal & $17.4 \%(4.3 \%)$ & $17.2 \%(25.2 \%)$ & $54.6 \%(50.9 \%)$ \\
Snowflake & $-(-)$ & $23.1 \%(8.4 \%)$ & $41.9 \%(38.9 \%)$ \\
\hline
\end{tabular}

(a) $\mathrm{CT}$

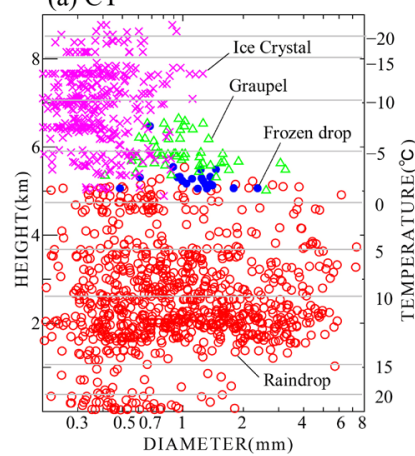

(c) ST

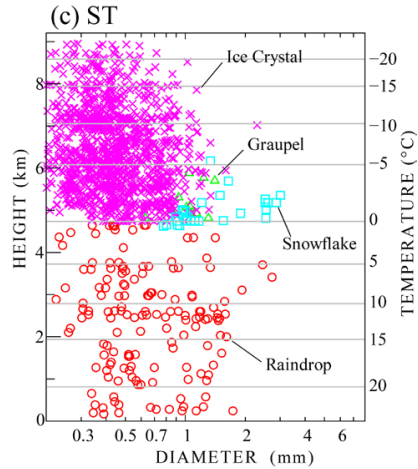

(d)

(i) CT $5.06 \mathrm{~km}$

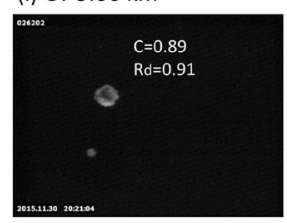

(iv) CT $5.31 \mathrm{~km}$

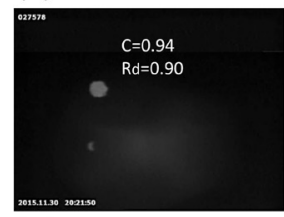

(vii) ECT $5.19 \mathrm{~km}$

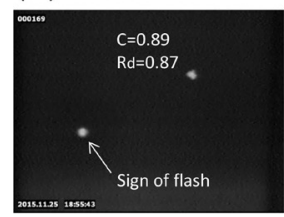

(ii) CT $5.15 \mathrm{~km}$

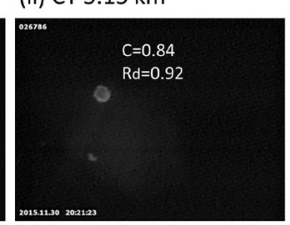

(v) CT $5.62 \mathrm{~km}$

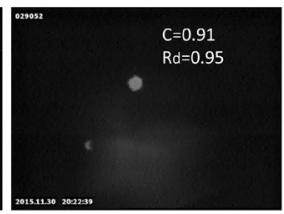

(viii) ECT $5.68 \mathrm{~km}$

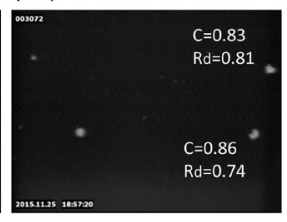

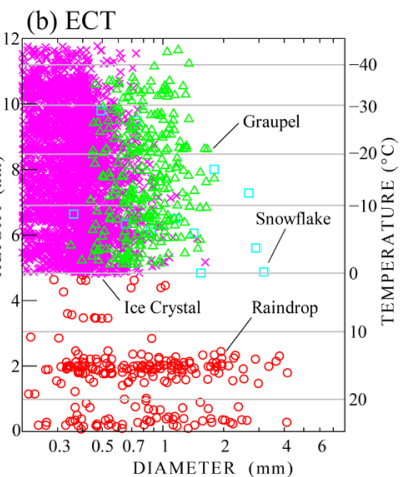

DIAMETER $(\mathrm{mm})$
Fig. 3. Size-height diagrams of the precipitation particles observed by (a) videosonde-CT (ascent at 20:03 LST on 30 November 2015), (b) videosonde-ECT (18:40 LST on 25 November 2015), and (c) videosonde-ST (21:06 LST on 15 December 2015). Open circles, solid circles, triangles, crosses and squares indicate raindrops, frozen drops, graupel, ice crystals and snowflakes, respectively. (d) Particle images transmitted from videosonde-CT and videosonde-ECT. C and $R_{d}$ indicate the circularity and the diameter ratio of the particle, respectively. Width of the images is $22 \mathrm{~mm}$.

\subsection{Case of a typical stratiform cloud (ST)}

Around noon on 15 December during the MJO active phase, a large cloud system over $100 \mathrm{~km}$ in diameter appeared over the ocean to the south of the R/V Mirai and moved northward. The leading edge of the cloud system passed over the R/V Mirai around 19:00 LST and over the Bengkulu observation site around 20:00 LST. A videosonde (hereafter referred to as videosonde-ST) was launched into a broad stratiform region at 21:06 LST. Mod- 
erate rainfall of $10 \mathrm{~mm} / \mathrm{h}$ continued at the Bengkulu site. The $\mathrm{R} /$ V Mirai radar showed a clear bright band, which indicates that this was a typical stratiform rain system (Fig. 2c). Videosonde-ST transmitted images of raindrops $>1 \mathrm{~mm}$ in diameter below the freezing level and snowflakes at around the $0^{\circ} \mathrm{C}$ level (Fig. 3c). A large number of ice crystals observed between 5 to $9 \mathrm{~km}$ in altitude of the cloud indicated active ice formation. Fewer graupel were observed by videosonde-ST in this case, similar to the precipitation particle distributions observed in a stratiform cloud during Baiu monsoon season (Suzuki et al. 2016).

\section{Discussion}

Figure 4 shows the relationship between the circularity and the diameter ratio of graupel and frozen drops recorded by videosonde-CT and videosonde-ECT. Figure $3 \mathrm{~d}$ shows particle images transmitted from videosondes with information of the circularity and the diameter ratio. The circularity and diameter ratio of graupel obtained from videosonde-CT had a narrower distribution than those obtained from videosonde-ECT between 0 and $-10^{\circ} \mathrm{C}$ in the cloud. The averages of the graupel circularity and diameter ratio were 0.84 and 0.88 for videosonde-CT, respectively, and 0.85 and 0.81 for videosonde-ECT, respectively. This indicated that the graupel obtained from videosonde-CT were more spherical than the irregular-shaped graupel from videosondeECT. In addition, the distribution of frozen drops observed by videosonde-CT corresponded with the graupel distribution. The averages of the circularity and diameter ratio of the frozen drops were 0.85 and 0.89 , respectively. The mean diameters of the graupel and frozen drops in the videosonde-CT observation were 1.12 and $1.23 \mathrm{~mm}$, respectively, while that of the graupel in the videosonde-ECT observations was $0.86 \mathrm{~mm}$ (no frozen drop), which was smaller than for the typical convective case (CT). These features suggested different graupel formation processes in different cloud types. The large circularity and diameter ratio of the graupel indicated that small raindrops uplifted by the strong updraft froze, and then worked as embryos for graupel formation. As a result, spherical graupel were dominant just above the freezing level in the convective cloud. This graupel formed through this freezing-riming process just above $0^{\circ} \mathrm{C}$ level might have a frozen drop as an embryo. Therefore, the water could concentrate efficiently around the $0^{\circ} \mathrm{C}$ level in the cloud because the frozen drop has larger density than the ice crystal.

On the other hand, graupel formation was active in the upper

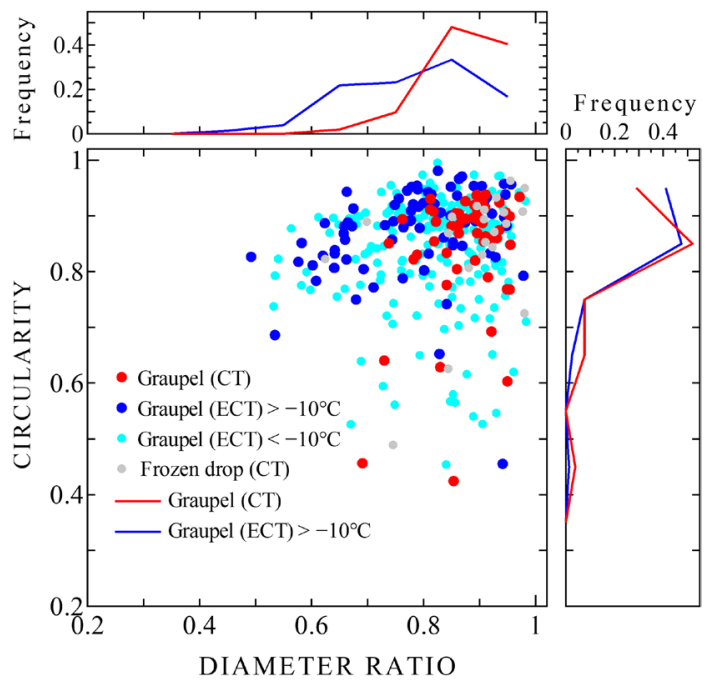

Fig. 4. Scatter diagram of the circularity and the diameter ratio of graupel and frozen drops obtained from videosonde-CT and videosonde-ECT. Upper and right-hand panels show the frequency of the diameter ratio and the circularity, respectively. anvil cloud with shallow convection (ECT), which was different from the typical stratiform cloud case (ST). The circularity and diameter ratio of the graupel observed in the upper layer varied between 0.4 and 1.0. This indicated the graupel were irregular-shaped with complicated outlines and their origins were from ice crystals. It was suggested that supercooled droplets were uplifted by the convergence of the outer flow from the neighboring strong convective cloud, and ice crystals in the upper anvil cloud extended from the neighboring convective cloud played a role as embryos for the formation of irregular-shaped graupel. Table 1 shows the volume ratio calculated as the proportion of volume for each particle to the total volume of the precipitation particles throughout the cloud. The volume ratio of graupel in the ECT case was larger than that in the ST case. In the typical stratiform cloud (ST), precipitation was mostly produced from ice crystals and snowflakes. On the other hand, in the ECT, graupel with larger density than ice crystals appear to enhance rainfall, although the relation with the density needs to be considered further.

The updraft in a cloud is also one of important factors to know the precipitation process. Although balloon-borne radiosonde sounding cannot measure the updraft/downdraft in clouds directly, the tendency of vertical winds in a cloud can be discussed using the averaged ascent rate of a radiosonde (Asai 1968). Figure 5 shows the vertical profile of the deviation of the ascent rate from the average throughout the cloud. For the CT, the downdraft (or weak updraft) was expected to be dominant below the freezing level, due to the drag force from large raindrop formation and the negative buoyancy by raindrop evaporation, and the updraft just below the freezing level that assisted graupel formation. For the ECT, the expected-updraft just below the freezing level would suggest that the supercooled droplets were lifted and enhanced the riming process. The profile obtained from videosonde-ST showed that a weak updraft was expected to be below the freezing level. In the convective cloud (CT), it was supposed that frozen drops were produced by the updraft and graupel with large circularity and diameter ratio were formed by the riming of frozen drops. In the stratiform cloud with a lower shallow convection (ECT), supercooled droplets were uplifted by the updraft in the shallow convective cloud, and irregular-shaped graupel formed from ice crystals. Unfortunately, the videosonde cannot detect small cloud particles such as supercooled droplets due to the limitation of the sensor performance. Simultaneous observation with other sensors to detect small cloud particles will be necessary in our future work.

\section{Summary}

Videosondes were launched into different rain systems that developed over the southwestern coast of Sumatra Island, Indonesia, during the Pre-YMC project. Quantitative evaluations of graupel shapes obtained from videosondes were performed for convective and stratiform clouds, and the thick upper stratiform cloud with

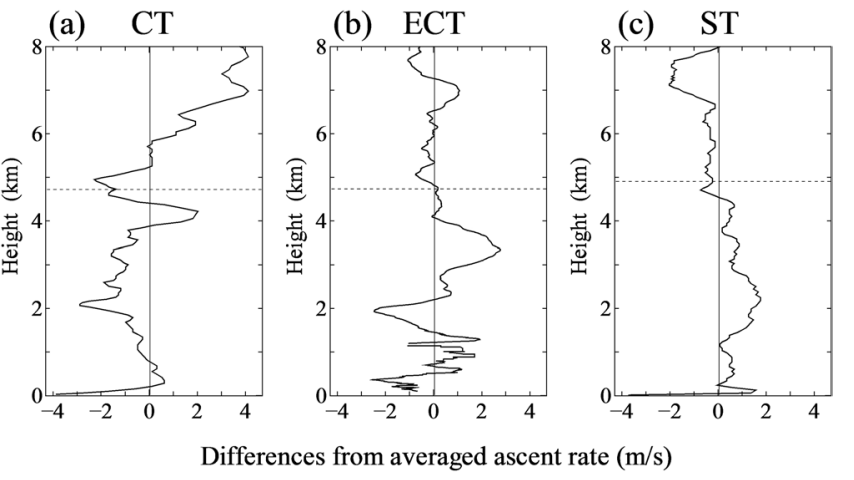

Fig. 5. Vertical profiles of the differences in the averaged videosonde ascent rates $\left(\mathrm{m} \mathrm{s}^{-1}\right)$. (a) videosonde-CT, (b) videosonde-ECT, and (c) videosonde-ST. Short lines indicate the altitudes of the $0^{\circ} \mathrm{C}$. 
shallow convection. It is effective to examine the circularity and the diameter ratio of graupel obtained from the particle image analysis, which are closely related with the graupel growth. The results suggested different graupel formation processes occurred in different rain systems. Different embryos for the graupel, which have different densities, may be related to the acceleration of water concentration in clouds and rain enhancement, although the additional studies (e.g., continuous launchings of videosondes into the same rain system at short-time intervals) will be needed for further understanding of solid hydrometeor processes in clouds.

\section{Acknowledgements}

The videosonde observation was conducted as part of the PreYMC field campaign conducted by the Japan Agency for MarineEarth Science and Technology. We sincerely appreciate the many researchers who joined the Pre-YMC project from JAMSTEC, $\mathrm{BPPT}$ and BMKG for their support in conducting the videosonde observations. The present study was supported by the Japan Aerospace Exploration Agency (JAXA) Precipitation Measuring Mission (PMM) research program under Grant JX-PSPC-378948, JX-PSPC-418469 and JX-PSPC418374. Thanks are extended to the Indonesian Ministry of Research, Technology and Higher Education for issuing research permit for the campaign with special support from the Japanese Embassy.

Edited by: T.-Y. Koh

\section{References}

Asai, T., 1968: An analysis of convective activity in the atmosphere using rawinsonde data. Tenki, 15, 109-115.

Harimaya, T., 1976: The embryo and formation of graupel. $J$. Meteor. Soc. Japan, 54, 42-51.

Knight, C. A., and N. C. Knight, 1973: Conical graupel. J. Atmos. Sci., 30, 118-124.

Mori, S., J.-I. Hamada, Y. I. Tauhid, M. D. Yamanaka, N. Okamoto, F. Murata, N. Sakurai, H. Hashiguchi, and T. Sribimawati, 2004: Diurnal land-sea rainfall peak migration over Sumatra Island, Indonesia maritime continent observed by TRMM satellite and intensive rawinsonde soundings. Mon. Wea. Rev., 132, 2021-2039.

Mori, S., J.-I. Hamada, N. Sakurai, H. Fudeyasu, M. Kawashima, H. Hashiguchi, F. Syamsudin, A. A. Arvain, R. Sulistyowati, J. Matsumoto, and M. D. Yamanaka, 2011: Convective systems developed along the coastline of Sumatera Island, Indonesia, observed with an X-band Doppler radar during the HARIMAU2006 campaign. J. Meteor. Soc. Japan, 89A, 61-81, doi:10.2151/jmsj.2011-A04.

Muramoto, K., K. Matsuura, and T. Shiina, 1993: Analysis of snowflake shape by a region and contour approach. IEICE, J76-D-II, 5, 949-958.

Ogino, S.-Y., M. D. Yamanaka, S. Mori, and J. Matsumoto, 2016: How much is the precipitation amount over the tropical coastal region? J. Climate, 29, 1231-1236, doi:10.1175/ JCLI-D-15-0484.1.

Suzuki, K., K. Shimizu, T. Ohigashi, K. Tsuboki, S. Kawamura, K. Nakagawa, K. Yamaguchi, and E. Nakakita, 2012: Development of a new videosonde observation system for in-situ precipitation particle measurement. SOLA, 8, 1-4.

Suzuki, K., M. Matsuo, E. Nakano, S. Shigeto, K. Yamaguchi, and E. Nakakita, 2014: Graupel in the different developing stages of Baiu monsoon clouds observed by videosondes. Atmos. Res., 142, 100-110.

Suzuki, K., N. Munechika, K. Nakagawa, K. Yamaguchi, and E. Nakakita, 2016: Simultaneous measurements of a stratiform cloud by multipoint videosonde launchings. SOLA, 12, 1013.

Takahashi, T., 1990: Near absence of lightning in torrential rainfall producing Micronesian thunderstorms. Geophys. Res. Lett., 17, 2381-2384.

Takahashi, T., and K. Kuhara, 1993: Precipitation mechanisms of cumulonimbus clouds at Pohnpei, Mirconesia. J. Meteor. Soc. Japan, 71, 21-31.

Takahashi, T., K. Suzuki, M. Orita, M. Tokuno, and R. de la Mar, 1995: Videosonde observations of precipitation processes in equatorial cloud clusters. J. Meteor. Soc. Japan, 73, 509534.

Takahashi, T., T. Tajiri, and Y. Sonoi, 1999: Charges on graupel and snow crystals and the electrical structure of winter thunderstorms. J. Atmos. Sci., 56, 1561-1578.

Takahashi, T., and T. D. Keenan, 2004: Hydrometeor mass, number, and space charge distribution in a "Hector" squall line. J. Geophys. Res., 109, D16208, 10.1029/2004JD 004667.

Takahashi, T., 2006: Precipitation mechanisms in east Asia monsoon: Videosonde study. J. Geophys. Res., 111, D09202, doi:10.1029/2005JD006268.

Takayabu, Y. N., 2002: Spectral representation of rain profiles and diurnal variations observed with TRMM PR over the equatorial area. Geophys. Res. Lett., 29, 30-31, doi:10.1029/ $2001 \mathrm{GL} 014113$.

Watanabe, R., K. Suzuki, T. Kawano, and S. Sugimoto, 2014: Microphysical structures of early-winter snow clouds during a cold air outbreak of December 23-25, 2010. SOLA, 10, 62-66.

Wu, P., D. Ardiansyah, S. Yokoi, S. Mori, F. Syamsudin, and K. Yoneyama, 2017: Why torrential rain occurs on the western coast of Sumatra Island at the leading edge of the MJO westerly wind bursts. SOLA, 13, 36-40, doi:10.2151/sola. 2017-007.

Yokoi, S., S. Mori, M. Katsumata, B. Geng, K. Yasunaga, F. Syamsudin, Nurhayati, and K. Yoneyama, 2017: Diurnal cycle of precipitation observed in the western coastal area of Sumatra Island: Offshore preconditioning by gravity waves. Mon. Wea. Rev., 145, 3745-3760, doi:10.1175/MWR-D-160468.1.

Manuscript received 10 July 2018, accepted 18 September 2018 SOLA: https://www.jstage.jst.go.jp/browse/solal 